\title{
Phytoremediation: Sulphonated Aromatic Pollutants
}

\section{Sulphonated Aromatic Pollutants}

\section{Limits of Microbial Degradability and Potential of Phytoremediation}

\author{
Jean-Paul Schwitzguébel ${ }^{1 *}$, Sylvie Aubert ${ }^{1}$, Wolfgang Grosse ${ }^{2}$ and Frank Laturnus ${ }^{3}$ \\ ${ }^{1}$ Laboratory for Environmental Biotechnology (LBE), Swiss Federal Institute of Technology Lausanne (EPFL), \\ $\mathrm{CH}-1015$ Lausanne, Switzerland \\ ${ }^{2}$ Institute of Botany, University of Cologne, Gyrhofstrasse 15, D-50931 Koeln, Germany \\ ${ }^{3}$ Department of Chemistry, University of Copenhagen, Symbion Science Park, Fruebergvej 3, DK-2100 Copenhagen $\varnothing$, \\ Denmark
}

* Corresponding author (jean-paul.schwitzguebel@epfl.ch)

\section{DOI: http://dx.doi.org/10.1065/espr2001.09.084.4}

Abstract. Many synthetic sulphonated aromatic compounds are used as starting material to produce dyes and pigments, or are released as by-products in the effluents of the textile and dye industry. A large number of these chemicals are poorly biodegradable and cannot be eliminated by classical wastewater treatment plants. To limit the impact of these pollutants on the environment, new processes, based on the use of higher plants (constructed wetlands or hydroponic systems), are under development. Detergents and surfactants are essential for both industrial and domestic applications, the most important family being the alkylbenzene sulphonates. Originally, the alkyl side chains were branched and thus recalcitrant to biodegradation. Therefore, they have been replaced by linear alkylbenzene sulphonates. Although more acceptable, present formulations still have adverse environmental and toxic effects. In this context, phytoremediation appears to be a promising approach to remove these compounds from contaminated soils and waters.

Keywords: Biodegradability; detergents; dyes; industrial effluents; LAS (linear alkylbenzene sulphonates); linear alkylbenzene sulphonates (LAS); pigments; phytoremediation; sulphonated aromatic compounds; surfactants; wastewater treatment

\section{Introduction}

Whereas naturally produced, and biologically degradable, sulphonated organic compounds are mostly aliphatic (taurine, coenzyme $M$, cysteate, methanesulphonate, sulphoacetate, sulpholactate, plant sulpholipids), only a few natural aromatic sulphonates are known, like aeruginosin B produced by Pseudomonas species, and some undefined compounds present in marine sediments and soils, largely in humic materials. In contrast, the sulphur present in organic synthetic compounds is mostly found in the form of a sulphonate moiety $\left(-\mathrm{SO}_{3}{ }^{-}\right)$bound to one or several carbon(s) of an aromatic nucleus, as in the sulphonate dyes, the linear alkylbenzene sulphonate surfactants and their by-products. Therefore, many sulphonated xenobiotics rejected in the environment are often only poorly biodegradable and thus the efficiency of classical biological wastewater treatment plants to cope with effluents containing such compounds is not always the best. Even if sulphonated aromatics are not considered as priority pollutants, their increasing production, use and release will become of concern in the near future (Cook et al. 1999, Nigam et al. 2000, Riediker et al. 2000, Robinson et al. 2001).

The present review aims to address the environmental problems linked with two families of sulphonated aromatic compounds: dyes and pigments, as well as linear alkylbenzene sulphonate surfactants. The state-of-the-art knowledge on the toxicity, microbial degradability, impact and behaviour of such xenobiotics in the environment will be presented. The recent and promising developments of phytoremediation, i.e. the use of green plants and their associated micro-organisms, to remove, contain and/or render harmless environmental pollutants, will be emphasized, especially to treat wastewater containing sulphonated aromatic compounds.

\section{Dyes and Pigments}

\subsection{Structure, use and toxicity}

More than $10^{6}$ tons of at least 10,000 different synthetic dyes and pigments are produced annually worldwide. Of this amount, approximately 280,000 tons are discharged every year into the environment (Willetts and Ashbolt 2000), mainly via industrial effluents, but also via leachates from landfills (Riediker et al. 2000). Synthetic anthraquinone is the parent compound for a large palette of dyes and an important starting material in their production, via anthraquinone sulphonates (Fig. 1), giving to this family of chemicals an actual impact on the environment, especially rivers. Benzene sulphonate and $p$ toluene sulphonate are used as intermediates in the manufacture of optical brighteners, pickling agents, dyestuffs, tanning agents, insecticides, surfactants, wetting agents and antioxidants. They are also used as acidic catalysts and standardizing agents in dyestuff manufacture. As for naphthalene sulphonic acids, they are important precursors for dye intermediates, wetting agents and dispersants.

It is not only the colour of these organic compounds that render their release into the environment unacceptable, but 
<smiles>O=C1c2ccccc2C(=O)c2ccccc21</smiles><smiles>O=C1c2cccc(S(=O)(=O)O)c2C(=O)c2cccc(S(=O)(=O)O)c21</smiles>

AQ-1,5-SS<smiles>O=c1c2c(=O)c3cccc(S(=O)(=O)O)c3c=2c(=O)c2ccccc12</smiles><smiles>O=C1c2ccccc2C(=O)c2cc(S(=O)(=O)O)ccc21</smiles><smiles>O=C1c2cccc(S(=O)(=O)O)c2C(=O)c2cccc(S(=O)(=O)O)c21</smiles>

AQ-1,8-SS

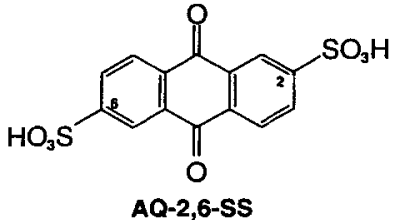

Fig. 1: Anthraquinone and sulphonated derivatives

their increasing discharge into water bodies and domestic wastewater treatment plants is causing significant concerns to environmental regulatory agencies (Banat et al. 1996). Information on the toxicology of many sulphonated aromatic compounds is rather scarce (Greim et al. 1994). These molecules, regardless of their structure and the way or duration of their application, seem to have a low systemic toxicity and seem to be neither carcinogenic nor mutagenic. The acute toxicity of sulphonated xenobiotics to rats is low, regardless of their particular structure. The hydrophilic properties of the sulphonic acids result in their rapid excretion from the organism, several of them without any biotransformation. Findings on irritation and skin sensitisation do not indicate any common effect for the group. However, more detailed studies are required with different sulphonated xenobiotics to assess their toxicity.

\subsection{Impact and behaviour in the environment}

Because they contain at least one sulphonic group and often also varying substitutions such as nitro groups, these aromatic compounds are not uniformly susceptible to bio-decolourisation and biodegradation in conventional wastewater treatment plants. Actually, the organosulphonate group plays an important role not only in altering the solubility and dispersion properties of the xenobiotic molecule, but also in increasing its recalcitrance to environmental breakdown, because of the thermodynamically stable carbon-sulphur bond (Kertesz et al. 1994). In addition, these aromatics are also highly mobile in aquatic systems (Angelino et al. 1999).

Effluents from the detergent, dye and textile industry are thus often contaminated with sulphonated aromatic compounds. Consequently, pollution of many European rivers by sulphurorganic xenobiotics is largely due to this class of chemicals (Young and Yu 1997). Furthermore, it has recently been reported that benzene and naphthalene sulphonates are also found in plumes and leachates from landfills (Riediker et al. 2000).

Data available on more than 20 sulphonated aromatic compounds show distinct ecotoxicological properties of these xenobiotics (Greim et al. 1994). First of all, their biodegradability seems highly variable, and many of these compounds must be categorized as recalcitrant. For example, no degradation was observed for six of the eight naphthalene sul- phonic acids listed. The $\log \mathrm{K}_{\mathrm{ow}}$ (where $\mathrm{K}_{\mathrm{ow}}$ is the octanolwater partition coefficient) for all benzene, stilbene, diphenyl, naphthalene and other sulphonic acids tested was determined to be equal to or less than 2.2. Therefore, no significant accumulation in the fats of living organisms is expected. The value of acute toxicity to fish is greater or equal to $100 \mathrm{mg} / \mathrm{L}$. for most of the aromatic sulphonic acids tested. However, due to the poor biodegradability and varying values for fish toxicity of these compounds, the release of industrial effluents containing significant amounts of such compounds into rivers can have deleterious effects on the organisms living in such waters.

Sulphonated aromatics can be adsorbed on algae or plant residues (Fernandez et al. 1996, Nigam et al. 2000), whereas cells isolated from rhubarb can accumulate this class of xenobiotics (Schwitzguébel 1996, Duc et al. 1999 a and b). Preliminary experiments with different species show that whole plants can also accumulate these compounds. Thus, sulphonated xenobiotics could possibly enter the food chain, either directly via the water supply, or after sorption by plants.

\subsection{Treatment possibilities}

Colour removal has been largely investigated during the last two decades. Several physico-chemical decolourisation techniques have been reported, like coal adsorption or $\mathrm{UV} / \mathrm{H}_{2} \mathrm{O}_{2}$ treatment (Yang et al. 1998). However, their expensiveness, low efficiency and inapplicability to a wide variety of dyes have inhibited their development and use.

Since dyes and by-products usually contain a wide variety of substituted sulphonated aromatic compounds, the substrate spectrum of bacteria has been intensively investigated with regard to their possible application for the treatment of industrial wastewater and to the cost-effectiveness of such an approach. Unfortunately, microbial degradation of these pollutants often requires unusual catabolic activities rarely found in a single species (Ohe et al. 1990, Dangmann et al. 1996, Seignez et al. 1996, Cook et al. 1999, Ruff et al. 1999). An important step in the biodegradation appears to be catalysed by dioxygenases adding oxygen across the double bond bearing the sulphonate group, leading to its elimination (Kuhm et al. 1991, Contzen et al. 1996). Thus, special attention has been paid to the substrate specificity of dioxygenases, often consid- 
ered as a rate-limiting step for the mineralization of sulphonated aromatic compounds. Unfortunately, a rather limited substrate range has been observed for bacterial isolates and the accumulation of dead-end products often occurs (Nörtemann et al. 1994). The decolourisation of several synthetic dyes including azo and anthraquinone derivatives has also been examined in white-rot fungal cultures, known to produce ligninase and other peroxidases (Muralikrishna and Renganathan 1993, Young and Yu 1997). However, an inhibition seems to occur at rather low concentrations, depending on the individual dye structure. Furthermore, the production of the key enzyme responsible for dye decolourisation, lignin peroxidase, is dependent on carbon or nitrogen limitation, which is usually not the case for industrial effluents (Wong and Yu 1999). These negative features limit the efficiency and, therefore, the use of conventional bio-filters and wastewater treatment plants, because of the limited ability of micro-organisms to degrade sulphonoaromatic compounds, and thus to cope with various mixtures of these xenobiotics.

In this context, the development of alternative biological treatments to eliminate these pollutants from industrial effluents is a requirement (Robinson et al. 2001). More precisely, selected plant species are able to remove pollutants from wastewater, by the use of constructed wetlands (Biddlestone et al. 1991, Davies and Cottingham 1994) or hydroponic type treatment plants (Furukawa and Fujita 1993). Both offer a potentially low cost, low maintenance biological method for wastewater treatment. Most of the systems currently in use have been designed to treat domestic wastewater, but have a great potential to remove a wide range of xenobiotics and to treat industrial effluents containing recalcitrant organics such as priority pollutants and dyes (Davies and Cottingham 1994).

Even if phytoremediation has developed mostly for polluted soil decontamination (Salt et al. 1998, Siciliano and Germida 1998), the use of green plants and plant material to treat water contaminated with xenobiotic compounds appears as a promising approach (Dec and Bollag 1994, Low et al. 1995, Hughes et al. 1997, Medina et al. 2000). Plant metabolism is diverse and can be exploited to treat recalcitrant compounds not degradable by bacteria. To develop such phytoremediation treatments, isolated plant cells cultivated in vitro offer many advantages over the whole plants. In particular, the screening of plant species as to their ability to degrade or remove xenobiotics belonging to the same chemical family is made easier and quicker (Harms 1992, Hughes et al. 1997, Schwitzguébel et al. 1998, Vanek et al. 1998). Such an approach has been used for the development of a novel treatment to eliminate several sulphonated aromatic pollutants from wastewater.

Whereas benzene sulphonate (BS) and $p$-toluene sulphonate $(p-\mathrm{TS})$ are moderately biologically degradable (Khlebnikov et al. 1997), the biodegradation of many substituted benzene sulphonates is difficult or even impossible. Therefore, industrial effluents containing a mixture of such compounds are not suitable for treatment in biological wastewater treatment plants. This family of xenobiotics therefore has to be considered as a potential and actual cause of pollution for soils and waters (Riediker et al. 2000).

The ability of the bacterium Comamonas testosteronii to attack $p$-TS is dependent on the activity of both mono and dioxygenases. Since the synthesis of betalain pigments by red beetroot also involves the activity of a dioxygenase, this enzyme could possibly accept $p$-TS and BS as substrates. Cells isolated from red beetroot (Beta vulgaris) were thus tested for their ability to degrade or transform these compounds. Cells were grown in shake flasks in the presence of the xenobiotic compounds added at different times. After incubation, cells were separated from the growth medium by filtration and the filtrate was analysed by High Performance Liquid Chromatography (HPLC), Capillary Electrophoresis (CE) and spectrophotometry for its content in the parent compounds and, eventually, in metabolites derived from them. The most significant results are summarized below (Table 1, part a).

Table 1: Present knowledge on the fate of different aromatic sulphonated compounds by plant cells

\begin{tabular}{|c|c|c|c|}
\hline Compound & Accumulation & Transformation & Desulphonation \\
\hline \multicolumn{4}{|l|}{ Part a } \\
\hline $\mathrm{BS}^{\mathrm{b}}$ & +++ & $?$ & $?$ \\
\hline $\mathrm{p}-T S^{b}$ & +++ & $?$ & $?$ \\
\hline \multicolumn{4}{|l|}{ Part b } \\
\hline$A Q-1-S^{r}$ & ++++ & ++ & $?$ \\
\hline$A Q-2-S^{\prime}$ & ++ & $+\overline{+++}$ & ++ \\
\hline$A Q-1,5-S S^{\prime}$ & ++++ & $?$ & $?$ \\
\hline$A Q-1,8-S S^{\prime}$ & ++++ & $?$ & $?$ \\
\hline $\mathrm{AQ}-2,6-\mathrm{SS}^{\prime}$ & ++ & $?$ & $?$ \\
\hline \multicolumn{4}{|l|}{ Part c } \\
\hline $\mathrm{I}^{\prime}$ & ++ & + & $?$ \\
\hline$\| I^{\prime}$ & ++++ & ++ & $?$ \\
\hline $1 \mathrm{II}^{\mathrm{r}}$ & +++ & +++ & ++ \\
\hline IV' & ++ & $?$ & $?$ \\
\hline $\mathrm{V}^{r}$ & ++ & ++ & $?$ \\
\hline \multicolumn{4}{|c|}{$\begin{array}{l}{ }^{\mathrm{b}}=\text { red beetroot cells; }{ }^{\mathrm{r}}=\text { rhubarb cells } \\
\mathrm{I}=2 \text {-chloro-5-nitro-benzene sulphonic acid } \\
I I=2 \text {-hydroxy-4-sulpho- } 1 \text {-naphthalenediazonium }\end{array}$} \\
\hline
\end{tabular}


When added at $900 \mathrm{mg} / \mathrm{L}$, the highest uptake rate of $p$-TS was observed if the xenobiotic was given during the exponential phase of growth: $22 \mathrm{mg} / \mathrm{L}$ per day, leading to an overall decrease of one third within two weeks. If the xenobiotic was present from the beginning of the growth, no uptake was observed during the first 7 days, but the uptake rate reached a value of $19 \mathrm{mg} / \mathrm{L}$ per day from the seventh day of incubation. If given during the stationary phase, the uptake rate of $p$-TS was only $10 \mathrm{mg} / \mathrm{L}$ per day. In contrast, the highest uptake rate of BS, given at $900 \mathrm{mg} / \mathrm{L}$, was observed if added to red beetroot cells after 15 days of cultivation (stationary phase): $43 \mathrm{mg} / \mathrm{L}$ per day, leading to a decrease of more than $30 \%$ of its initial concentration within a week. If BS was present from the beginning of cultivation, no uptake was observed during the first 7 days. However, the uptake rate reached a value of $29 \mathrm{mg} / \mathrm{L}$ per day from the seventh day of incubation. An uptake rate of $29 \mathrm{mg} / \mathrm{L}$ per day was also observed if BS was added after 7 days of cultivation (exponential phase), leading to a removal of more than $40 \%$ of the xenobiotic within 16 days. It is not yet known if both xenobiotic compounds are transformed by beetroot cells, or only accumulated.

Different derivatives of anthraquinone naturally occur in several plant genera like Rheum (rhubarb), Rumex and Rubia (Trease and Evans 1983, Van den Berg and Labadie 1989). Rhubarb could thus possess enzymes capable of accepting sulphonated anthraquinones as substrates. Cells were isolated from Rheum palmatum and grown in shake flasks or in bioreactors in the presence of up to $700-800 \mathrm{mg} / \mathrm{L}$ anthraquinones with sulphonate groups in different positions (Fig. 1). The position of the sulphonated moiety on the aromatic ring structure, rather than the number of such groups, appears to be the main factor controlling the fate of the xenobiotic in rhubarb cells (Table 1, part b): simple uptake from the medium, transformation, desulphonation, conjugation or partial degradation (Schwitzguébel et al. 1995, Schwitzguébel 1996, Schwitzguébel et al. 1996).

Rhubarb cells are also able to efficiently accumulate other sulphono-aromatics rejected by the dye industry, like 2-chloro5-nitro-benzene sulphonate 2-hydroxy-4-sulpho- and 2-hydroxy-4-sulpho-6-nitro-naphthalene-diazonium, as well as 1,3naphthalene disulphonates, containing either an amino or a nitro group in position 7. Furthermore, rhubarb cells transform four of these compounds without releasing any intermediate (Table 1, part c, and Schwitzguébel 1998, Duc et al. 1999, a and b).

Based on the promising results obtained with different sulphonated aromatic compounds of the same family, future environmental applications can be considered. Further studies, however, are required to characterize and better understand the biochemical mechanisms leading to the accumulation, the transformation and/or the degradation of sulphonated xenobiotics in isolated cells and whole rhubarb plants. On the other hand, this hardy plant species could be a good candidate to develop biological processes to treat wastewaters and sites contaminated with sulphonated aromatic pollutants. In the future, whole plants grown in the field could help to decontaminate soils or groundwater, whereas rhubarb or Rumex cultivated under hydroponic conditions could be used to treat wastewater containing sulphonated derivatives of benzene, toluene, naphthalene or anthraquinone.

\section{Surfactants}

\subsection{Use, structure, determination, and toxicity}

Use and structure. In the middle of the 20th century, when the use of washing-machines was getting popular in Europe, soap was replaced by detergents with about $15 \%(\mathrm{v} / \mathrm{v})$ surfactants in washing powder and up to $45 \%(\mathrm{v} / \mathrm{v})$ in liquid detergents (Stache and Kosswig 1990). Although worldwide soap is still used more than surfactants, the wide variety of processes in which surfactants are involved has resulted in a significant increase in their consumption from about $13^{*} 10^{6}$ tons in 1977 to $18^{*} 10^{6}$ tons in 1996 (Granados 1996). Of this total, some $1.5^{*} 10^{6}$ tons per year correspond to the anionic linear alkylbenzene sulphonates (LAS) (Fig. 2), the leading type of surfactants in term of volume consumption (Krueger et al. 1998a, Perales et al. 1999a). They are widely

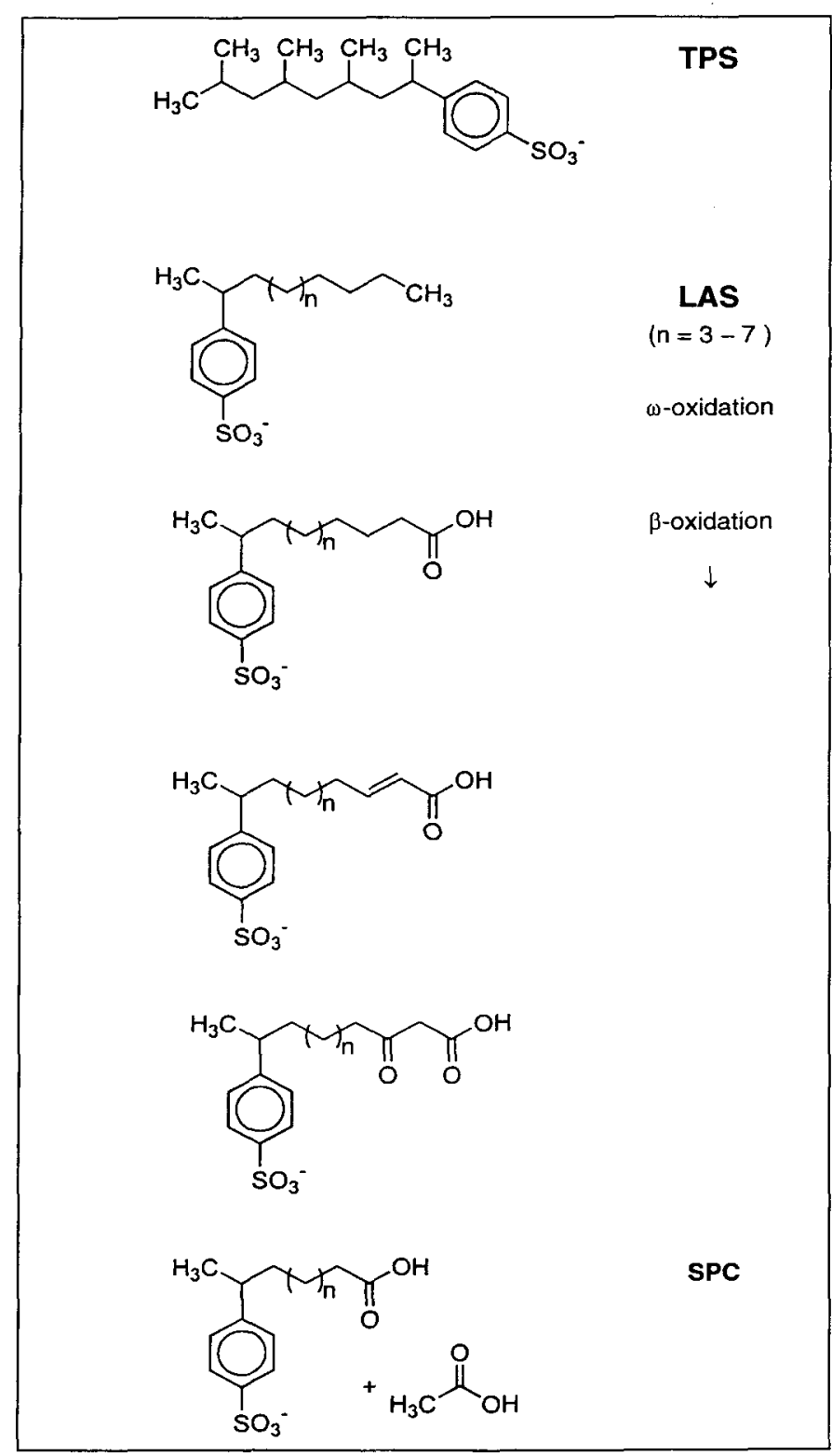

Fig. 2: Chemical structures of tetrapropylbenzene sulphonate (TPS), linear alkylbenzene sulphonate (LAS), and intermediates of bacterial biodegradation of LAS to sulphophenyl carbonylate (SPC) by $\omega$-oxidation followed by $\beta$-oxidation 
used as ingredients in detergents, personal care and household cleaning products, but also in a variety of industrial and commercial applications.

LAS consists of two moieties, (i) a sulphonated aromatic benzene ring of variable positioning is fixed at (ii) a linear aliphatic chain containing from 10 to $14 \mathrm{C}$-atoms (C-10 to C14). Since the tetrapropylbenzene sulphonate (TPS) (Fig. 2) primarily used, which is most recalcitrant due to its branched side-chain, was naturally degraded very slowly and insufficiently, the environment and drinking water showed a high pollution by these compounds (Malz 1980). Therefore, it has been replaced by the less recalcitrant LAS, mainly due to the easier natural degradation and mineralization by different bacterial mechanisms.

LAS are produced from straight-chain hydrocarbons isolated from the kerosene fraction of petroleum by molecular-sieve chromatography (Henkel 1976), followed by benzoylation and the final sulphonation (Stache and Grossmann 1985). The final commercial product is a mixture of several homologues of LAS roughly consisting of $4-6 \% \mathrm{C}-10,43-49 \%$ $\mathrm{C}-11,36-40 \% \mathrm{C}-12,10-13 \% \mathrm{C}-13$, and $1 \% \mathrm{C}-14$, respectively, and of isomers resulting from the different positions the benzene-sulphonate moiety is fixed at the linear sidechain including the terminal position (Hellmann 1995).

Determination. Anionic surfactants are commonly measured by the methylene blue method as described for example by the German standard method DIN 38409-H23-1 (DEV-9, Edition 1981). Both water-soluble cationic methylene blue and anionic surfactant react to a less water-soluble complex, which can be easily extracted from the aqueous samples for being well soluble in chloroform and trichloromethane, respectively, and finally quantified spectrophotometrically. Unfortunately, the same methylene blue complexes are formed also by some biogenic anions, which commonly occur in environmental samples, mimicring the presence of surfactants. On the other hand, the occurrence of anionic surfactants may be masked by their reaction with quaternary ammonium compounds in displacing methylene blue in the complex. This is also the case when cationic surfactants are available in the same sample (Hellmann 1995).

During the last decade, new analytical methods have been developed for environmental screening. Distribution of LAS and their potential sulphonated and non-sulphonated metabolites in natural waters was assessed in using, for instance, HPLC (Sarrazin et al. 1997). More recently, a biosensor was developed for monitoring LAS content in water (Nomura et al. 1998).

Since the lack of more specific detection methods was obvious, as well as information on metabolites, their level and toxicity in water, the European PRISTINE research project (ENV4-CT97-0494) was established in 1997 as one of the three 'Waste Water Cluster' projects to develop specific methods (Knepper and Kruse 2000, Li and Schroeder 2000, Riu et al. 1999 and 2000) for simultaneous identification and quantification of surfactants and their metabolites in European aquatic environments, fixed at different matrices or accumulated by marine organisms, e.g. fish (Diplodus vulgaris) and clam (Ruditapes semidecussatus), with special emphasis on monitoring the fate and toxicity of these com- pounds. To determine LAS adsorbed in sediments, pressurized liquid extraction followed by ion-pair derivatization GCMS was used (Ding and Fann 2000).

Toxicity. When acute (LC-48 h) and chronic (NOEC 21 days) toxicity studies were performed according to the OECD202 guidelines, with various LAS homologues versus marine (e.g. Nanochloropsis gladitana) and freshwater (e.g. Scenedesmus subspicatus) algae for hazard assessment, the assays show a remarkable effect of increasing molecular mass. The EC-50\% ( $24 \mathrm{~h}$ to $96 \mathrm{~h}$ ) ranges are between 9.8 and $6.0 \mathrm{mg} / \mathrm{L}$ for $\mathrm{Na}-\mathrm{LAS} \mathrm{C}-10$ versus $\mathrm{N}$. gladitana. The toxicity (EC-50\%; $24 \mathrm{~h}$ to $72 \mathrm{~h}$ ) increases with $1.1 \mathrm{mg} / \mathrm{L}$ for Na-LAS C-12 to $0.6 \mathrm{mg} / \mathrm{L}$ for Na-LAS C-14. In assessing the freshwater algae $S$. subspicatus, the toxicity (EC-50\%; 24 to $72 \mathrm{~h}$ ) with $48 \mathrm{mg} / \mathrm{L}$ for Na-LAS C-12 is about one order of magnitude lower than in marine environment (Moreno 2000). Among the freshwater plankton, the ciliates and heterotrophic nano-flagellates are the most sensitive groups with non-effect concentrations (NEC) as low as $0.02 \mathrm{mg}$ LAS/L. Most other planktonic organisms are affected at concentrations higher than normally found in aquatic habitats. Exceptions to the general trend are the photosynthetic activity of the phytoplankton and the cryptophyte abundance which both are nearly as sensitive parameters as protozoan abundance (Jorgensen and Christoffersen 2000).

Changes in embryonic development of the seabream Sparus aurata are observed with the five LAS (C-10 to C-14) homologues, commercial LAS mixture ( $\mathrm{Na}$ and $\mathrm{Mg}$ salts), and the degradation intermediate SPC C-11. In studying survival and hatching rate of eggs by exposing them to increasing concentrations of these surfactants, the $\mathrm{LC}_{50}$ values for the different LAS homologues decrease with increase of the alkyl-chain length. In general, $\mathrm{LC}_{50}$ values for LAS (C-10 and C-11) homologues are about one order of magnitude higher than that of the LAS (C-12 to C-14) homologues and the commercial LAS. Commercial LAS produce approximately $90 \%$ of mortality at $0.5 \mathrm{mg} / \mathrm{L}$, whereas at $0.25 \mathrm{mg} / \mathrm{L}$ the survival of the exposed organisms is similar to the control. With the degradation intermediate SPC C-11, no mortality is observed over the entire experimental concentration range. In general, the $\mathrm{LC}_{50}$ of eggs-larvae of $S$. aurata versus LAS seems much higher than the LAS concentrations usually found in marine environments (Hampel et al. 2000a).

Several homologues of LAS inhibit enzymes related to cellular protection mechanisms (e.g, glyoxalase, cholinesterase, acid phosphatase), using gills of Ruditapes philippinarum as a target organ (Hampel and Blasco, unpublished). The inhibiting effect on glyoxalase activity, similar for all tested homologues, occurs above $10 \mathrm{mmol} / \mathrm{L}$. No activity at all is found at concentrations higher than $50 \mathrm{mmol} / \mathrm{L}$. But, by measuring the effect of $0-100 \mathrm{mg} / \mathrm{L}$ LAS (C-11 and C-13) on marine micro-algae Tetraselmis chuii, esterase activity is significantly more inhibited by LAS $\mathrm{C}-13$ than by LAS C11. Whereas a significant decrease of activity is observed at $1.0 \mathrm{mg} / \mathrm{L}$ LAS C-13, no significant difference can be seen between control and organisms exposed to $\mathrm{C}-10$ homologue (Hampel et al. 2000b). 
Estrogenic activity. Due to their similar chemical properties with the estrogenic alkylphenolpolyethoxylates, LAS and degradation metabolites could have some estrogenic activity. However, using in vitro bioassays, the yeast estrogene receptor assay and the vitellogenin assay with cultured trout hepatocytes, no estrogenicity is observed for any of the tested compounds (Navas et al. 1999). The estrogenicity studies by in vivo tests, utilising Wistar female rats as test animals and the increase of uterine weight as an estrogenic factor, corroborate these results. Other than Bisphenol A ( $800 \mathrm{mg} / \mathrm{kg}$ body weight) and DES, the Na-LAS C-12 does not show any estrogenic activity under the same conditions (Moreno 2000).

\subsection{Impact and behaviour in the environment}

Non-point source pollution. Commercial surfactants, used in equal amounts by private households and industry, are complex mixtures of homologues and isomers of anionic, nonionic, cationic and amphoteric compounds. They are commonly discharged completely by waste effluents and a huge amount of synthetic surfactants, and degradation products occur in marine and freshwater environments. As long as sewage water is not discharged in an untreated form, the wastewater treatment plants processing municipal or industrial effluents are the main source of environmental pollution by surfactants and their degradation products. The direct discharge of small volumes of wastewater containing LAS in natural water may not be a major problem, as the observed biodegradation values are higher than 96\% (Ferrer et al. 1996).

Degradation efficiency of wastewater treatment plants is variable, but a shift of LAS ratio is observed during the passage of the sewage water through the treatment plants. Compared to the LAS homologue distribution normally observed in influent samples, it is significantly shifted towards the shorter alkyl chain species. The concentrations of the higher homologues LAS C-13 and LAS C-12 are predominantly reduced for the increasing degradation rate along with an increasing of the side-chain length of LAS homologues. For example, in comparison to the homologue ratio of commercial LAS, with 31100,88 , and 60 for LAS C-10 through LAS C-13, respectively, the LAS ratio shifted in influents of 5 wastewater treatment plants near Barcelona, Spain, to $73-$ 100 (LAS C-10), 82-100 (LAS C-11), 6-27 (LAS C-12), 0-4 (LAS C-13), in the range of about $0.5-1.2 \mathrm{mg} \mathrm{LAS} / \mathrm{L}$.

Anionic surfactants with their high solubility predominantly occur in the aqueous phase and are attached at minor amounts to soil or sediment particles. However, terrestrial environments may also be contaminated, especially when sewage sludges are used as fertilisers (Fox et al. 1997, Cavalli and Valtorta 1999).

Environmental distribution. Since LAS and the degradation intermediate sulphophenyl carbonylate (SPC) are the predominant surfactants continuously discharged to the recipients (Table 2), it is not surprising that rivers are commonly contaminated in highly varying concentrations as shown by a survey on German rivers with LAS concentrations of 1 $1,400 \mu \mathrm{g} / \mathrm{L}$. Transport of LAS occurs with about $90 \%$ in the aqueous phase and $10 \%$ attached at suspended particles (Hellmann 1995). Therefore, LAS content in river sediments, resulting from suspended particles, is usually not higher than $10 \%$ of the LAS content in the aqueous phase. LAS pollution in the same range with highest values of $135 \mu \mathrm{g} / \mathrm{L}$ was measured in the Lao-Jie River in Taiwan. This is a typical Eastern-Asian river, with less than $5 \%$ of all discharged municipal wastewater treated by wastewater treatment plants so that large quantities of the surfactant residues in the wastewater are discharged directly into the river and ocean (Ding et al. 1999). LAS pollution is not a specific feature of freshwater, but also accounts for marine ecosystems. Studies in the Bay of Cadiz, Spain, have shown a related level of pollution by the common LAS and SPC homologues (Table 3) up to $447 \mu \mathrm{g} / \mathrm{L}$ (LAS C-11) and $64 \mu \mathrm{g} / \mathrm{L}$ (SPC C-8), respectively (Riu et al. 1999). Since LAS is not

Table 2: Concentration ranges of selected surfactants in municipal wastewater passing wastewater treatment plants partly receiving run-off from textile industry (adapted from www.pristine-wwc.de)

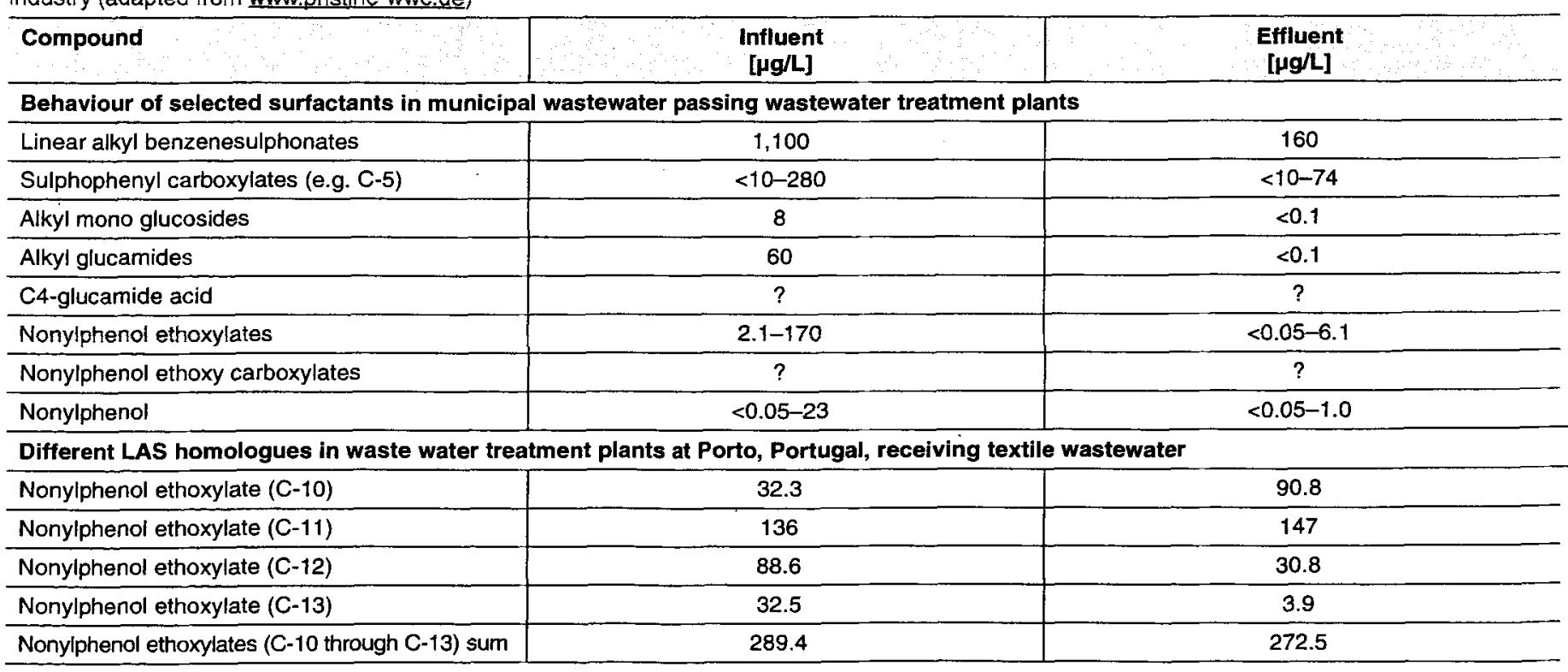




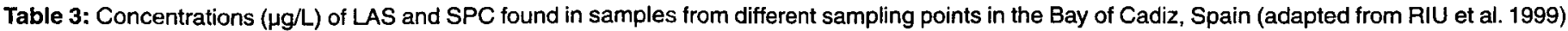

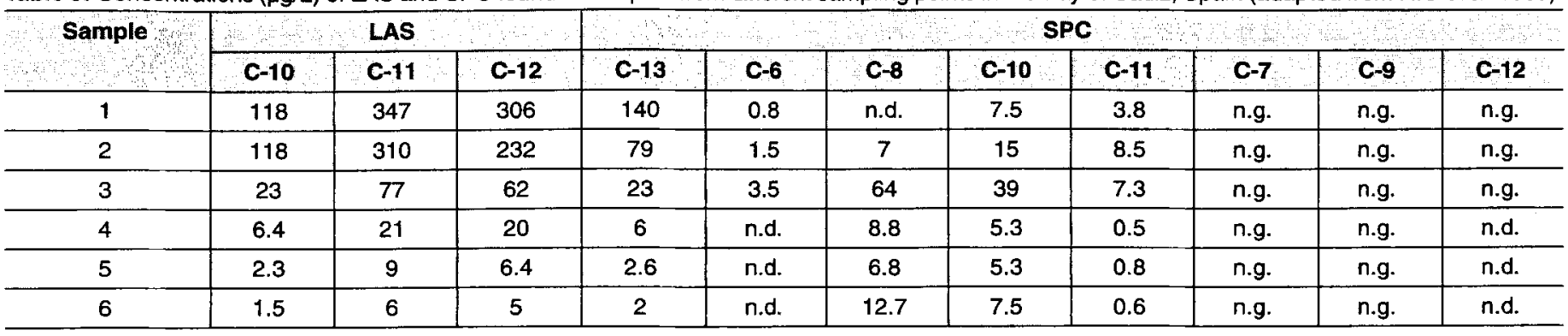

n.d.: not detected; n.g.: not quantified

degraded sufficiently in anaerobic sewage sludge digesters (De Wolf and Feijtel 1998, Krueger et al. 1998b), significant amounts of surfactants are applied to agro-ecosystems when that sludge is used for fertiliser in agriculture.

Degradation - Microbial degradation of LAS via sulphophenyl carboxylates (SPC) is the main decontamination process in aqueous solution, sludge, and soil (Fig. 2). Terminal $\omega$-oxidation of the side-chain is the initiating reaction. Then a step by step shortening of the side-chain by $\beta$-oxidation follows before the final mineralization to $\mathrm{CO}_{2}, \mathrm{H}_{2} \mathrm{O}$, and $\mathrm{SO}_{4}{ }^{2-}$ occurs by ring cleavage, desulphonation, and oxidation (Hrsak and Grbic-Galic 1995, Denger and Cook 1997, Cook et al. 1999, Perales et al. 1999b, Schleheck et al. 2000, Schulz et al. 2000), with specific contributions of bacterial biofilm aggregations under experimental as well as environmental conditions (Boeije et al. 2000). Environmental parameters (e.g., temperature, $\mathrm{pH}$, redox potential) modulate the biodegradation process, but do not substantially alter it (Perales et al. 1999a). From the degradation of such mixtures of LAS homologues and isomers, a large set of intermediates can be expected. That makes it extremely difficult to determine their levels in aqueous habitats, sediments, sewage, and sludgefertilized soil contaminated with surfactants and their metabolites, and to correlate the various surfactants with their toxicity and environmental impact.

\subsection{Remediation possibilities}

As LAS is used as a detergent agent, it mainly enters the environment via industrial and domestic sewage (Krueger et al. 1998b). Significant quantities of LAS co-products, like dialkyltetralin sulphonates and LAS with single methyl branching on the alkyl chains (iso-LAS), can be found in sewage too (Nielsen et al. 1997). The removal and degradation of LAS and co-products already start when entering the sewer system (Moreno et al. 1990, Holt et al. 1998). The sewer lines contribute up to $60 \%$ to the removal and are an effective first step in urban effluent treatment: the biodegradation is influenced by the length of the sewer lines and the conditions of aeration. At present, the most effective methods for the remediation of sewage contaminated by LAS are municipal and industrial wastewater treatment plants based on aeration/settling, activated sludge/aerobic digestion of sludge, or activated sludge/anaerobic digestion of sludge (Berna et al. 1989). LAS and co-products entering the treat- ment plants through the sewage influents are degraded up to $99.7 \%$ of the influent concentrations (Berna et al. 1989, Field et al. 1992, Nielsen et al. 1997, Waters et al. 2000), with half-lives in the range of 1-2 days for activated sludge (Krueger et al. 1998b). LAS and most of the co-products undergo extensive mineralization $(>50 \%)$ and ultimate biodegradation $(80-90 \%$ mineralization plus conversion to biomass), but release some (10-20\%) of their carbons as water-soluble intermediates (Nielsen et al. 1997). When sewage farms or trickling filters are used to clean-up sewage, LAS removal was reported for 80 to $89 \%$ of the influent concentrations (Rapaport and Eckhoff 1990, Boeije et al. 2000).

However, LAS is persistent in oxygen-depleted groundwater and sewage-contaminated groundwater (Barber et al. 1995, Krueger et al. 1998b), as well as in anaerobic sewage sludge digesters (De Wolf and Feijtel 1998, Krueger et al. 1998b). Especially in Europe and North America, large amounts of sewage sludge are applied to agricultural fields for fertilization. The concentrations of LAS reported in anaerobic digested sludge are 1 to 2 orders of magnitude greater than those observed for aerobically digested sludge (McAvoy and Eckhoff 1993). Despite the fact that LAS in anaerobic digested sludge can be removed to nearly $100 \%$ by composting with an average half-life between 7 and 9 days (Prats-Rico et al. 1999), large-scale application of sewage sludge and wastewater effluents to soil has led to concerns about the potential accumulation of surfactants in soil environments (Kloepper-Sams et al. 1996, Nielsen et al. 1997). Although the use of LAS in surfactant-enhanced remediation of sewagecontaminated and ex situ soil washing is of recent interest (Deshpande et al. 1998, Krueger et al. 1998 a and b, Goudar et al. 1999), the presence of LAS and co-products in the agro-ecosystem is of particular concern because they can be transferred to humans via agricultural products or by leaching to groundwater (Laturnus et al. 1999). Thus, biodegradation should be an important process for removing surfactant residues from the terrestrial environment.

In the soil, bacteria are involved in the biodegradation of LAS and co-products (Branner et al. 1999). Surfactants like LAS can alter subsurface microbial populations by increasing the abundance of free-living bacteria (Barber et al. 1995). In the marine environment, LAS mineralization is carried out by bacterial associations rather than by single organisms (Vives-Rego et al. 2000). However, the sorption of LAS 
to sludge solids and soil components reduce the bioavailability to terrestrial organisms (Kloepper-Sams et al. 1996). Furthermore, seasonal variations apparently have an influence on the degradation of LAS by micro-organisms in soil and water, as higher microbial activity occurred during summer (Knaebel et al. 1990, Takada et al. 1992). For example, in a small wetland of $474 \mathrm{~m}^{2}$, the natural purification of LAS was assessed (Inaba 1992). The study involved adsorption on sediment particles and bacterial degradation in the wetland, and showed that biodegradation but not adsorption was affected by temperature as no degradation occurred in winter. During a one-year study of the degradation of LAS in sewage sludge-treated soil, a very fast decrease in concentration ( $>80 \%$ ) was observed within the first month. A removal of up to $96 \%$ was also observed by a passage of LAS contaminated water through a two-chamber constructed wetland with tropical/subtropical vegetation (Grosse et al. 1999). A significant shift of soil bacteria to gamma and delta Proteobacteria sub-classes, as well as a significant increase of Planctomycetes in the root zone areas after LAS application could be detected by whole cell hybridization techniques using Cy3-labeled rRNA-targeted oligonucleotide probes specific for different taxonomic levels (Roisch et al., submitted for publication).

However, in sludge-treated soil and landfills, a residual LAS concentration remains even after 320 days (Marcomini et al. 1989). The use of plants may increase the availability of sorbed LAS to terrestrial organisms, and, therefore, phytoremediation may be a suitable tool to degrade the part of the LAS, which could not be removed in wastewater treatment plants. It has been shown in greenhouse experiments that the growth of crops like barley and carrots can reduce LAS added to the soil by sewage sludge (Laturnus et al. 1999, Grøn et al. 2000). The increased degradation is probably due to enhanced soil aeration, and, therefore, stimulated microbial activity induced by the root growth. The additional aeration of the soil may also support the aerobic degradation of LAS. However, when high sludge doses are transferred to the soil, the degradation may be hindered, as LAS present in the sludge particles may not be available for biodegradation (Grøn et al. 2000). The greenhouse studies showed that there is no uptake of LAS to the green parts of the crops used, and only negligible concentration are found in the plant roots (Grøn et al. 2000). Apparently, most of the LAS are degraded and the degradation products released into the atmosphere, as studies with radio-labelled LAS showed (Figge and Schoberl 1989). At present, the general theme is that LAS does not pose a risk to terrestrial organisms such as plants and invertebrates (De Wolf and Feijtel 1998), and that LAS are biodegraded and have no effect on the growth of crops when applied to soil by sewage sludge (Gilbert and Kleiser 1988, Laturnus et al. 1999, Grøn et al. 2000). However, the addition of LAS has a suppressive effect on the elongation of the rice plant, inhibits water absorption by the roots, and affects photosynthesis, as leafs turn yellow after treatment (Taniyama 1978). For crops grown in soils treated with LAS containing sewage sludge, no such effect has been observed. When sewage sludge is applied to soil for the purpose of discharge, the growth of plants would support and increase the degradation of LAS added with the sludge.

\section{Outlook}

It is a prerequisite that plants used in any phytoremediation or rhizofiltration process are resistant/tolerant to the pollutants to be removed. Sulphonated aromatic pollutants are not detrimental to isolated rhubarb cells cultured in vitro. Whole rhubarb plants can also germinate, grow and develop in the presence of significant amounts of such xenobiotics, comparable to those found in industrial effluents: plant material is thus screened against several sulphonated aromatic pollutants, chosen to represent contaminants of current concern, having a range of physico-chemical properties (solubility, $\mathrm{K}_{\mathrm{ow}}$ ), these characteristics being significant for the breakdown process. Not only rhubarb, but also other plants producing anthraquinones, like Rumex and Rubia, should be tested. As a comparison, non-producing anthraquinones plants, like celery and aquatic plants, will be grown in the presence of different sulphonoaromatics. Plants selected for their tolerance have then to be tested for growth under hydroponic conditions and for their ability to remove sulphonoaromatics from contaminated water. If the pollutant under investigation disappears from the liquid medium, then its possible adsorption, accumulation and/ or decomposition by the plant should be estimated, and the possible role of micro-organisms associated with roots evaluated. The accumulation of the parent compounds and/ or metabolites possibly derived from them should be determined by extraction of different parts of the plants and appropriate analyses. The rates and yields of pollutant removal calculated per unit biomass should be used as one of the technological criteria to choose the most appropriate plant species for the treatment of effluents from the dye and textile industry.

Although LAS and their known degradation intermediates seem to be the less serious compounds among surfactants, some environmental risks may still exist. This should arise for the environment from LAS and SPC residues accumulated to higher concentrations by absorption under specific soil and sediment conditions. Acute and chronic health effects may be expected in mammals and humans, when LAS together with other xenobiotics come into contact with the skin or are accumulating in their organs. Problems are postulated, for example, for workers handling pesticides inappropriately, due to contaminated clothing that has been laundered and residues of xenobiotics and LAS commonly used for washing clothes, remain on the fabrics and together come into contact with the skin.

The observed toxicity, especially on marine algae, may induce shifts in the algae populations with unfavourable impact on the food chain in the marine ecosystems. No information is presently available on the impact of LAS and 
derivatives on the micro-loop, as a most important part of the food chain. Such effects should be expected from the observed shift in bacterial populations following LAS application to constructed wetlands, but also from the observed sensibility of some planktonic protozoans. Although, well operated wastewater treatment plants are reducing the LAS contents in treated sewage below environmentally risky concentrations on a global scale, the high discharge of untreated sewage effluents with high surfactant contents are still polluting river water and the oceans, which may be of some hazard to susceptible ecosystems. Therefore, the treatment of sewage effluents should be improved worldwide for reducing the environmental pollution, and higher plantbased approaches are promising for such a purpose.

\section{References}

Angelino S, Bianco Prevot C, Gennaro MC, Pramauro E (1999): Ion-interaction high-performance liquid chromatography and micellar electrokinetic capillary chromatography: two complementary techniques for the separation of aromatic sulfonated compounds. Journal of Chromatography A845, 257-271

Banat I, Nigam P, Singh D, Marchant R (1996): Microbial decolorization of textile-dye-containing effluents: a review. Bioresource Technology 58, 217-227

Barber LB, Krueger CJ, Metge DW, Harvey RW, Field JA (1995): Fate of LAS in groundwater - Implication for in situ surfactant enhanced remediation. ACS Symposium Series 595, 95-111

Berna JL, Ferrer J, Moreno A, Prats D, Ruiz Bevia F (1989): The fate of LAS in the environment. Tenside, Surfactants, Detergents 26, 101-107

Biddlestone AJ, Gray KR, Thurairajan K (1991): A botanical approach to the treatment of wastewaters. Journal of Biotechnology $17,209-220$

Boeije GM, Schowanek DR, Diederik R, Vanrolleghem PA (2000): Incorporation of biofilm activity in river biodegradation modelling: a case study for linear alkylbenzene sulphonate (LAS). Water Research 34, 1479-1486

Branner U, Mygind M, Jorgensen C (1999): Degradation of linear alkylbenzene sulfonate in soil columns. Environmental and Toxicological Chemistry 18, 1772-1778

Cavalli L, Valtorta L (1999): Surfactants in sludge-amended soil. Tenside, Surfactants, Detergents 36, 22-28

Contzen M, Wittich RM, Knackmuss HJ, Stolz A (1996): Degradation of benzene 1,3-disulfonate by a mixed bacterial culture. FEMS Microbiology Letters 136, 45-50

Cook AM, Laue H, Junker F (1999): Microbial desulfonation. FEMS Microbiology Reviews 22, 399-419

Dangmann E, Stolz A, Kuhm AE, Hammer A, Feigel B, NoisommitRizzi N, Rizzi M, Reuss M, Knackmuss HJ (1996): Degradation of 4-aminobenzenesulfonate by a two-species bacterial coculture. Biodegradation 7, 223-229

Davies TH, Cottingham PD (1994): The use of constructed wetlands for treating industrial effluents (textile dyes). Water Science and Technology 29 (4) 227-232

Dec J, Bollag JM (1994): Use of plant material for the decontamination of water polluted with phenols. Biotechnology and Bioengineering 44, 1132-1139

Denger K, Cook AM (1997): Assimilation of sulphur from alkyland arylsulfonates by Clostridium spp. Archives of Microbiology 167, 177-181
Deshpande S, Shiau BJ, Wade D, Sabatini DA, Harwell JH (1998): Surfactant selection for enhancing ex situ soil washing. Water Research 33, 351-360

DeWolf W, Feijtel T (1998): Terrestrial risk assessment for linear alkylbenzenesulfonates (LAS) in sludge-amended soils. Chemosphere 36, 1319-1343

Ding WH, Tzing SH, Lo JH (1999): Occurrence and concentrations of aromatic surfactants and their degradation products in river water of Taiwan. Chemosphere 38, 2597-2606

Ding WH, Fann JC (2000): Determination of linear alkylbenzenesulfonates in sediments using pressurized liquid extraction and ionpair derivatization gas chromatography-mass spectrometry. Analytica Chimica Acta 408, 291-297

Duc R, Vanek T, Soudek P, Schwitzguébel JP (1999a): Experimentation with Rhubarb in Europe. Soil and Groundwater Cleanup. February/March, 27-30

Duc R, Vanek T, Soudek P, Schwitzguébel JP (1999b): Accumulation and transformation of sulfonated aromatic compounds by rhubarb cells (Rheum palmatum). International Journal of Phytoremediation 1, 255-271

Fernandez N, Chacin E, Garcia C, Alastre N, Leal F, Forster CF (1996): The use of seed pods from Albizia lebbek for the removal of alkyl benzene sulphonates from aqueous solution. Process Biochemistry 31, 383-387

Ferrer J, Moreno A, Vaquero MT, Comellas L (1996): Monitoring of LAS in direct discharge situations - Untreated sewage and on sludge amended soils. In: Proceedings of 4th World Surfactants Congress, Asociacion Espanola de Productores de Sustancias papa Aplicaciones Tensiosctivas, Barcelona, Vol 3, pp 99-112

Field JA, Barber LB, Thurman EM, Moore BL, Lawrence DL, Peake DA (1992): Fate of alkylbenzenesulfonates and dialkyltetralinsulfonates in sewage-contaminated groundwater. Environmental Science and Technology 26, 1140-1148

Figge K, Schoberl P (1989): LAS and the application of sewage sludge in agriculture. Tenside, Surfactants, Detergents 26, 122-128

Fox KK, Chapman L, Solbe J, Brennand V (1997): Effect of environmentally relevant concentrations of surfactants on the desorption or biodegradation of model contaminants in soil. Tenside, Surfactants, Detergents 34, 436-441

Furukawa K, Fujita M (1993): Advanced treatment and food production by hydroponic type wastewater treatment plant. Water Science and Technology 28 (2) 219-228

Gilbert PA: Kleiser HH (1988): Assessing the environmental safety of LAS. Tenside, Surfactants, Detergents 25, 128-133

Goudar C, Strevett K, Grego J (1999): Competitive substrate biodegradation during surfactant-enhanced remediation. Journal of Environmental Engineering 125, 1142-1148

Granados J (1996): Surfactants raw materials. Constant evolution and a solid future. In: Proceedings of 4th World Surfactants Congress, Asociacion Espanola de Productores de Sustancias papa Aplicaciones Tensiosctivas, Barcelona, pp 100-123

Greim H, Ahlers J, Bias R, Broecker B, Hollander H, Gelbke H, Klimisch H, Mangelsdorf I, Paetz A, Schön N, Stropp G, Vogel R, Weber C, Ziegler-Skylakakis K, Bayer E (1994): Toxicity and ecotoxicity of sulfonic acids. Structure activity relationship. Chemosphere 28, 2203-2236

Grøn C, Laturnus F, Mortensen GK, Egsgaard H, Samsø-Petersen L, Ambus P, Jensen ES (2000): Plant uptake of LAS and DEHP from sludge-amended soil. In: Persistent Bioaccumulative Toxic Chemicals: Fate and Exposure. Eds Lipnick R, Muir D, Hermens J. ACS Symposium Series 772, pp 99-111

Grosse W, Wissing F, Perfler R, Wu Z, Chang J, Lei Z (1999): Biotechnological approach to water quality improvement in tropical 
and subtropical areas for reuse and rehabilitation of aquatic ecosystems. Consolidated final report. Project No ERBIC18CT960059 in Biotechnology of INCO-DC of the 4th Framework Programme of the European Commission, Brussels

Hampel M, Ortiz JB, Sarasquete C, Blasco J (2000a): Effects of homologues of linear alkylbenzene sulphonates (LAS C10 to C14) on survival of embryos and larvae of seabream (Sparus aurata). In Proceedings of 5th World Surfactants Congress, pp 1617-1626

Hampel M, Sobrino C, Lubian LM, Blasco J (2000b): Acute toxicity of LAS homologues in marine microalgae. Esterase activity and inhibition of growth as endpoints of toxicity. In: Proceedings of 5th World Surfactants Congress, pp 1627-1636

Harms HH (1992): In vitro systems for studying phytotoxicity and metabolic fate of pesticides and xenobiotics in plants. Pesticides Science 35, 277-281

Hellmann H (1995): Belastung von Flief3gewässern mit Tensiden Analytik und Ergebnisse. In: Handbuch Angewandte Limnologie V.2.3. Eds Steinberg C, Bernhardt H, Klapper $H$. ecomed verlagsgesellschaft, Landsberg, Germany

Henkel \& Cie (Ed), (1976): Waschmittelindustrie. 1. Edition, Hüthig-Verlag, Heidelberg, Germany

Holt MS, Fox KK, Burford M, Daniel M, Buckland H (1998): UK monitoring study on the removal of linear alkylbenzene sulfonate in trickling filter type sewage treatment plants. Science of Total Environment 210/211, 255-269

Hrsak D, Grgic-Galic D (1995): Biodegradation of linar alkylbenzene sulphonates (LAS) by mixed methanotrophic-heterotrophic cultures. Journal of Applied Bacteriology 78, 487-494

Hughes JB, Shanks J, Vanderford M, Lauritzen J, Bhadra R (1997): Transformation of TNT by aquatic plants and plant tissue cultures. Environmental Science and Technology 31, 266-271

Inaba K (1992): Quantitative assessment of natural purification in wetland for linear alkylbenzenesulfonates. Water Research 26, 893-898

Jorgensen E, Christoffersen K (2000): Short-term effects of linear alkylbenzene sulfonate on freshwater plankton studied under field conditions. Environmental Toxicology and Chemistry 19, 904-911

Kertesz MA, Cook AM, Leisinger T (1994): Microbial metabolism of sulfur- and phosphorus-containing xenobiotics. FEMS Microbiological Reviews 15, 195-215

Khlebnikov A, Zhoukov V, Péringer P (1997): Comparison of p-toluenesulphonic acid degradation by two Comamonas strains. Biotechnology Letters 19, 389-393

Kloepper-Sams P, Torfs F, Feijtel T, Gooch J (1996): Effects assessment for surfactants in sludge-amended soils - A literature review and perspectives for terrestrial risk assessment. Science of Total Environment 185, 171-185

Knaebel DB, Federle TW, Vestal JR (1990): Mineralization of LAS and linear alcohol ethoxylate in 11 contrasting sites. Environmental and Toxicological Chemistry 9, 981-988

Knepper TP, Kruse M (2000): Investigations on the formation of sulfophenylcarboxylic acids (SPC) out of linear alkylbenzenesulfonates (LAS) by means of liquid chromatography/mass spectrometry. Tenside, Surfactants, Detergents 37, 41-47

Krueger CJ, Barber LB, Metge DW, Field JA (1998a): Fate and transport of linear alkylbenzenesulfonate in a sewage-contaminated aquifer - A comparison of natural-gradient pulsed tracer tests. Environmental Science and Technology 32, 1134-1142

Krueger CJ, Radakovich KM, Sawyer TE, Barber LB, Smith RL, Field JA (1998b): Biodegradation of the surfactant linear alkylbenzenesulfonate in sewage-contaminated groundwater -
A comparison of column experiments and field tracer test. Environmental Science and Technology 32, 3954-3961

Kuhm AE, Stolz A, Ngai KL, Knackmuss HJ (1991): Purification and characterization of a 1,2-dihydroxynaphthalene dioxygenase from a bacterium that degrades naphthalenesulfonic acids. Journal of Bacteriology 173, 3795-3802

Laturnus F, Grøn C, Mortensen GK, Ambus P, Bennetzen S, Jensen ES (1999): Degradation of organic contaminants in sludgeamended agricultural soil. In: Proceedings of $5^{\text {th }}$ International In Situ and On-Site Bioremediation Symposium. Eds Leeson A, Alleman BC. Battelle Press, Columbus, Vol 6, pp 15-20

Li HQ, Schroeder HF (2000): Surfactants - Standard determination methods in comparison with substance specific mass spectrometric methods and toxicity testing by Daphnia magna and Vibrio fischeri. Water Science and Technology 42 (7-8) 391-398

Low KS, Lee CK, Tan KK (1995): Biosorption of basic dyes by water hyacinth roots. Bioresource Technology 52, 79-83

Malz F (1980): Der Hauptausschuß Detergentien - Modell zur Lösung von Umweltproblemen. Tenside, Surfactants, Detergents 17, 314-318

Marcomini A, Capel PD, Lichtensteiger T, Brunner PH, Giger W (1989): Behavior of aromatic surfactants and PCBs in sludgetreated soil and landfills. Journal of Environmental Quality 18, 523-528

McAvoy DC, Eckhoff WS (1993): Fate of linear alkylbenzene sulfonate in the environment. Environmental Toxicology and Chemistry 12, 977-987

Medina VF, Larson SL, Bergstedt AE, McCutcheon SC (2000): Phyto-removal of trinitrotoluene from water with batch kinetic studies. Water Research 34, 2713-2722

Moreno A (2000): Status report 4 of Pristine - ENV4-CT97-0494

Moreno A, De Ferrer J, Berna JL (1990): Biodegradability of linear alkybenzenesulfonate in a sewer system. Tenside, Surfactants, Detergents 27, 312-315

Muralikrishna C, Renganathan V (1993): Peroxidase-catalyzed desulfonation of 3,5-dimethyl-4-hydroxy and 3,5-dimethyl-4aminobenzenesulfonic acids. Biochemical and Biophysical Research Communications 197, 798-804

Navas J, Gonzáles-Mazo E, Wenzel A, Gomez-Parra A, Segner H (1999): Linear alkylbenzene sulfonates and intermediate products from their degradation are not estrogenic. Marine Pollution Bulletin 38, 880-884

Nielsen AM, Britton LN, Beall CE, McCormick TP, Russell GL (1997): Biodegradation of coproducts of commercial linear alkylbenzene sulfonates. Environmental Science and Technology 31, 3397-3404

Nigam P, Armour G, Banat IM, Singh D, Marchant R (2000): Physical removal of textile dyes from effluents and solid-state fermentation of dye-adsorbed agricultural residues. Bioresource Technology 72, 219-226

Nomura Y, Ikebuburo K, Yokoyama K, Takeuchi T, Arikawa Y, Karube I (1998): Application of a linear alkylbenzene sulfonate biosensor to river water monitoring. Biosensors and Bioelectronics 13, 1047-1053

Nörtemann B, Kuhm AE, Knackmuss HJ, Stolz A (1994): Conversion of substituted naphthalenesulfonates by Pseudomonas sp. BN6. Archives of Microbiology 161, 320-327

Ohe T, Ohmoto T, Kobayashi Y, Sato A, Watanabe Y (1990): Metabolism of naphthalenesulfonic acids by Pseudomonas sp. TA2. Agricultural and Biological Chemistry 54, 669-675

Perales JA, Manzana MA, Sales D, Quiroga JM (1999a): Linear alkylbenzene sulphonates: biodegradability and isomeric com- 
position. Bulletin of Environmental Contamination and Toxicology 63, 94-100

Perales JA, Manzana MA, Sales D, Quiroga JM (1999b): Biodegradation kinetics of LAS in river water. International Biodeterioration and Biodegradation 43, 155-160

Prats-Rico D, Rodriguez Pastor M, De la Muela Chasco MA, Llamas Torregrosa J M, Moreno Davila A, De Ferrer Daroca J, Berna Tejero JL (1999): Elimination of xenobiotics during composting - A case study of LAS. Tenside, Surfactants, Detergents 36, 294-298

Rapaport RA, Eckhoff WS (1990): Monitoring linear alkyl benzene sulfate in the environment 1973-1986. Environmental Toxicology and Chemistry 9, 1245-1257

Riediker S, Suter MJF, Giger W (2000): Benzene and naphthalenesulfonates in leachates and plumes of landfills. Water Research 34, 2069-2079

Riu J, Gonzáles-Mazo E, Gomez-Parra A, Barceló D (1999): Determination of parts per trillion level of carboxylic degradation products of linear alkylbenzenesulfonates in coastal water by solid-phase extraction followed by liquid chromatography/ion spray/mass spectrometry using negative ion detection. Chromatographia 50, 275-281

Riu J, Eichhorn P, Guerro JA, Knepper TP, Barceló D (2000): Determination of linear alkylbenzenesulfonates in wastewater by automated solid phase extraction followed by capillary electrophoresis-UV and confirmation by capillary electrophoresis-mass spectrometry. Journal of Chromatography A889, 221-229

Robinson T, McMullan G, Marchant R, Nigam P (2001): Remediation of dyes in textile effluent: a critical review on current treatment technologies with a proposed alternative. Bioresource Technology 77, 247-255

Roisch U, Schroeder L, Grosse W (2001, submitted): Dynamics of plant-root-soil bacteria-associations in constructed wetlands caused by linear alkylbenzenesulphonates (LAS). Ecological Engineering

Ruff J, Hitzler T, Rein U, Ritter A, Cook AM (1999): Bioavailability of water-polluting sulfonoaromatic compounds. Applied Microbiology and Biotechnology 52, 446-450

Salt DE, Smith RD, Raskin I (1998): Phytoremediation. Annual Review of Plant Physiology and Plant Molecular Biology 49, 643-668

Sarrazin L, Arnoux A, Rebouillon P (1997): High-performance liquid chromatographic analysis of a linear alkylbenzenesulfonate and its environmental biodegradation metabolites. Journal of Chromatography A 31, 285-291

Schleheck D, Dong W, Denger K, Heinzle E, Cook AM (2000): An alpha-proteobacterium converts linear alkylbenzenesulfonate surfactants into sulfophenylcarboxylates and linear alkyldiphenyletherdisulfonate surfactants into sulfodiphenylethercarboxylates. Applied and Environmental Microbiology 66, 1911-1916

Schulz S, Dong W, Groth U, Cook AM (2000): Enantiomeric degradation of 2-(4-Sulfophenyl)Butyrate via 4-sulfocatechol in Delftia acidovorans SPB1. Applied and Environmental Microbiology 66, 1905-1910

Schwitzguébel JP, Vanek T, Mathieu N, Thirot JL, Novotny M (1995): Biotransformation of sulfonated xenobiotic compounds by plant cells. In: Biosorption and Bioremediation. Ed Macek T et al., Prague, pp L 2-10

Schwitzguébel JP (1996): Biodegradation of xenobiotics by plants. In: Kurzfassungen der DECHEMA-Jahrestagungen '96, Band I, DECHEMA, Frankfurt am Main, pp 442-443
Schwitzguébel JP, Thirot JL, Mathieu N, Novotny M, Vanek T (1996): Biotransformation of sulfonated aromatic compounds by plant cells. Experientia 52, A22

Schwitzguébel JP (1998): From plant cells to phytoremediation. In: Biotec' 98 - Book of abstracts. Eds Mota M, Ferreira EC. Braga, ISBN 972-97810-0-1, p 8

Schwitzguébel JP, Duc R, Vanek T (1998): Development of a biological process to treat industrial effluents and by-products using plant cells. In: Abstracts of Third Annual International Conference on Phytoremediation, June 22-25, Houston, TX, USA, p 10

Seignez C, Adler N, Suard JC, Péringer P (1996): aerobic and anaerobic biodegradability of 1-anthraquinone sulphonate. Applied Microbiology and Biotechnology 45, 719-722

Siciliano SD, Germida JJ (1998): Mechanisms of phytoremediation: biochemical and ecological interactions between plants and bacteria. Environmental Review 6, 65-79

Stache H, Grossmann H (1985): Waschmittel, 1. Edition, Springer Verlag, Berlin, Germany

Stache H, Kosswig K (1990): Tensid-Taschenbuch. 1. Auflage, Hansen-Verlag, München, Germany

Takada H, Ogura N, Ishiwatari R (1992): Seasonal variations and modes of riverine input of organic pollutants to the coastal zone - 1.Flux of detergent-derived pollutants to Tokyo Bay. Environmental Science and Technology 26, 2517-2523

Taniyama T (1978): Effects of various synthetic detergents on photosynthesis, dry matter and grain production in rice plants. Mie Daigaku Kankyo Kagaku Kenkyu Kiyo 3, 93-104 (in Japanese)

Trease GE, Evans WC (1983): Phenols and phenolic glycosides. In: Pharmacognosy, 12th edition, Baillière Tindall, London, pp 368-414

Van den Berg AJJ, Labadie RP (1989): Quinones. In: Methods in Plant Biochemistry, Volume 1, Plant Phenolics. Ed Harborne JB. Academic Press, London, pp 451-491

Vanek T, Soudek P, Hubalek M, Schwitzguébel JP, Duc R (1998): Plant cell cultures as a model system for phytoremediation. In: Proceedings of International Workshop on Innovative Potential of Advanced Biological Systems for Remediation. Ed Timmis KW. Hamburg, p 193

Vives-Rego; J, Lopez-Amoros R, Guindulain T, Garcia MT, Comas J, Sanchez-Leal J (2000): Microbial aspects of linear alkylbenzene sulfonate degradation in coastal water. Journal of Surfactants and Detergents 3, 303-308

Waters J, Lee KS, Perchard V, Flanagan M, Clarke P (2000): Monitoring of diester surfactant residues in UK and Dutch sewage treatment effluents. Tenside, Surfactants, Detergents 37, 161-171

Willetts J, Ashbolt N (2000): Understanding anaerobic decolourisation of textile dye wastewater: mechanism and kinetics. Water Science and Technology 42 (1-2), 409-415

Wong Y and Yu J (1999): Laccase-catalyzed decolorization of synthetic dyes. Water Research 33, 3512-3520

Yang Y, Wyatt DT, Bahorsky M (1998): Decolorization of dyes using $\mathrm{UV} / \mathrm{H}_{2} \mathrm{O}_{2}$ photochemical oxidation. Textile Chemist and Colorist 30 (4) 27-35

Young L, Yu J (1997): Ligninase-catalysed decolorization of synthetic dyes. Water Research 31, 1187-119

Received: February 14th, 2001

Accepted: November 15th, 2001

OnlineFirst: December 17th, 2001 